TEACHING : Jurnal Inovasi Keguruan dan IImu Pendidikan

Vol. 1. No. 4 Desember 2021 e-ISSN : 2775-7188 | p-ISSN : 2775-717X

\title{
PENGGUNAAN METODE PEMBELAJARAN CONTEXTUAL TEACHING LEARNING UNTUK MENINGKATKAN HASIL BELAJAR SISWA PADA MATERI RITEL
}

\author{
YUSNIAR \\ SMKN1 Tanjungpinang Provinsi Kepulauan Riau \\ Email : yusniar735@gmail.com
}

\begin{abstract}
ABSTRAK
Penelitian Tindakan Kelas ini bertujuan untuk mengetahui apakah ada pengaruh terhadap keberhasilan nilai belajar siswa dengan menggunakan Metode Pembelajaran Contextual Teaching Learning di SMK Negeri 1 Tanjungpinang tepatnya pada Kelas XI BDP 2. Jenis Penelitian Tindakan Kelas ini dengan menggunakan metode Deskriptif. Yaitu dimulai dari pengumpulan data, menganalisis data kemudian menginterpretasikannya. Data yang diperoleh diambil dari Siswa Siswi SMK Negeri 1 Tanjungpinang Kelas XIBDP 2, pada mata pelajaran Ritel. Yang dibentuk kedalam 6 kelompok belajar, masing-masing kelompok terdiri dari 6 orang siswa. Hal ini dilakukan pada Semester Ganjil. Penelitian Tindakan Kelas ini dilaksanakan sebanyak dua siklus, dimana setiap siklus dimulai dari tahapan perencanaan, pelaksanaan, pengamatan dan terakhir adalah refleksi. Hasil penelitian ini menggambarkan bahwa dengan menggunakan model pembelajaran kontekstual, persentase ketuntasan belajar siswa dapat meningkat dengan baik, bahkan tercapai sesuai dengan Nilai KKM. Hal ini dapat dibuktikan pada siklus I terlihat $51,72 \%$ tingkat ketuntasan dan $41,28 \%$ yang tidak tuntas. Sementara pada siklus II tercapai $89,66 \%$ tingkat ketuntasan belajar siswa dan 10,34\% yang tidak tuntas. Maka dari itu dapat dismpulkan bahwa dengan adanya perubahan model pembelajaran akan mengakibatkan suatu perubahan pola piker dan daya serap siswa, sehingga memperoleh hasil yang diharapkan atau hasil yang lebih baik.
\end{abstract}

Kata Kunci : Contextual Teaching Learning, Metode Pembelajaran, Hasil Belajar.

\section{ABSTRACT}

This Classroom Action Research aims to determine whether there is an effect on the success of student learning scores by using the Contextual Teaching Learning Learning Method at SMK Negeri 1 Tanjungpinang, precisely in Class XI BDP 2. This type of Class Action Research uses a descriptive method. That is, starting from collecting data, analyzing the data and then interpreting it. The data obtained were taken from students of SMK Negeri 1 Tanjungpinang Class XIBDP 2, in the Retail subject. Which was formed into 6 study groups, each group consisting of 6 students. This is done in Odd Semesters. This Classroom Action Research was carried out in two cycles, where each cycle started from the stages of planning, implementation, observation and finally reflection. The results of this study illustrate that by using the contextual learning model, the percentage of student learning mastery can increase well, even achieved in accordance with the KKM score. This can be proven in the first cycle seen $51.72 \%$ completeness level and $41.28 \%$ incomplete. Meanwhile, in the second cycle, $89.66 \%$ of students' learning mastery levels were achieved and $10.34 \%$ were incomplete. Therefore, it can be concluded that a change in the learning model will result in a change in the mindset and absorption of students, so as to obtain the expected results or better results.

Keywords: Contextual Teaching Learning, Learning Methods, Learning Outcomes.

\section{PENDAHULUAN}

Dalam rangka untuk meningkatkan mutu pendidikan, banyak faktor yang mempengaruhi keberhasilan belajar siswa, salah satunya adalah metode pembelajaran yang dilakukan guru di dalam kelas. Pembelajaran yang baik adalah pembelajaran yang berhasil dalam kegiatan proses dan hasil akhir berupa output nilai. Banyak sekali metode pembelajaran 
yang digunakan dalam proses belajar yang secara teori dapat mengangkat hasil belajar baik proses maupun hasil akhir berupa output nilai sebagai tolak ukurnya.

Seorang guru pasti menginginkan keberhasilan belajar bagi peserta didiknya, dengan kata lain hasil belajar siswa tersebut dapat melebihi atau paling tidak sama dengan KKM (Kriteria Ketuntasan Minimal) yang telah ditetapkan.

Untuk itu penulis sebagai guru dituntut untuk mencari metode pembelajaran yang dapat merangsang kegiatan siswa semaksimal mungkin sehingga proses belajar mengajar dapat terlaksana dengan baik. Penulis sebagai guru telah menggunakan metode - metode pembelajaran yang modern dan meninggalkan metode konvensional. Namun kenyataannya setelah menggunakan metode-metode yang modern tersebut belum menampakkan hasil yang maksimal bagi keberhasilan peserta didik.

Melihat hal tersebut diatas membuahkan suatu pertanyaan, mengapa hal tersebut bias terjadi? Kemungkinan alasan yang timbul banyak sekali, mungkin input siswa, kesalahan dalam menggunakan metode, ketidaktersedianya fasilitas, alasan lingkungan, motivasi atau mungkin penulis sebagai guru belum sempurna dalam menggunakan metode pembelajaran.

Maka dari itu timbul keinginan penulis untuk membuktikan kebenaran mengenai penggunaan metode pembelajaran yang dapat meningkatkan hasil belajar siswa yang dikhususkan pada metode pembelajaran Contextual Teaching Learning. Alasan penulis menggunakan metode ini, karena dalam kegiatan proses pembelajarannya siswa langsung terlibat.

Berdasarkan identifikasi dan pembatasan masalah maka dapat dirumuskan apakah dengan metode pembelajaran Contextual Teaching Learning dapat meningkatkan hasil belajar siswa pada mata pelajaran ritel di kelas XIBDP 2 pada semester ganjil di SMKN 1 Tanjungpinang.

Tujuan dilakukannya penelitian ini adalah untuk mengetahui pengaruh penggunaan metode pembelajaran Contextual Teaching Learning dalam pembelajaran ritel sehingga dapat meningkatkan penguasaan materi dan hasil belajar siswa Kelas XIBDP 2 di SMKN 1 Tanjungpinang pada semester ganjil.

\section{METODELOGI PENELITIAN}

Penelitian ini dilakkan di Sekolah Menengah Kejuruan Negeri 1 tanjungpinang, yang terletak di jalan Pramuka No. 06 Kecamatan Bukit Bestari Kota Tanjungpinang. Lingkungan fisik sekolah hampir memadai terhadap pendidikan. Jumlah kelas yang cukup untuk menampung keseluruhan jumlah siswa SMKN 1 yang berkisar 1.315 orang siswa, yang terdiri dari 7 program keahlian, jumlah siswa perkelas sekitar 29-35 orang siswa.

Untuk penelitian ini penulis hanya melakukan penelitian pada satu program keahlian yaitu Program Keahlian Pemasaran atau Bisnis Daring dan Pemasaran, yang hanya dijadikan subjek peneliti adalah kelas XIPM2. Yang jumlahnya 29 siswa. Subjek dalam penelitian ini penulis ambil hanya kelas XIPM2 Program Keahlian Pemasaran atau Bisnis Daring dan Pemasaran yang jumlah siswanya sebanyak 29 orang siswa. Alasan penulis memilih kelas XIPM2 sebagai subjek, karena KLS tersebut dalam proses pembelajaran masih banyak yang kurang nilainya terhadap kompetensi Ritel, sehingga tidak mencukupi KKM atau target yang ingin dicapai atau yang diharapkan.

Lama penelitian yang penulis lakukan 2 bulan yaitu minggu pertama Februari 2019 sampai dengan minggu terakhir dibulan Maret 2019. Disini penulis melakukan tindakan mulai dari minggu ke- 1 Februari sampai dengan minggu ke- 3 Maret 2019. Mencakup dua siklis yaitu siklus satu dan dua.

Penelitian yang akan penulis lakukan bermula dari Pra penelitian, kemudian dilanjutkan dengan siklus pertama yang dilakukan dengan cara pengamatan dan refleksi, setelah itu dilanjutkan lagi ke tahap siklus ke dua, apabila pada siklus pertama masih ditemukan kekurangan maka perencanaan dan pelaksanaan tindakan perbaikan masih dapat dilanjutkan pada siklus berikutnya sehingga mencapat target yang diinginkan. Dalam prosedur penelitian 
ini penulis menggunakan metode penelitian tindakan kelas dengan model Kurt Lewin, yang Konsep pokok penelitiannya mencakup empat komponen, ke empat komponen tersebut penulis lakukan disetiap siklus yaitu :

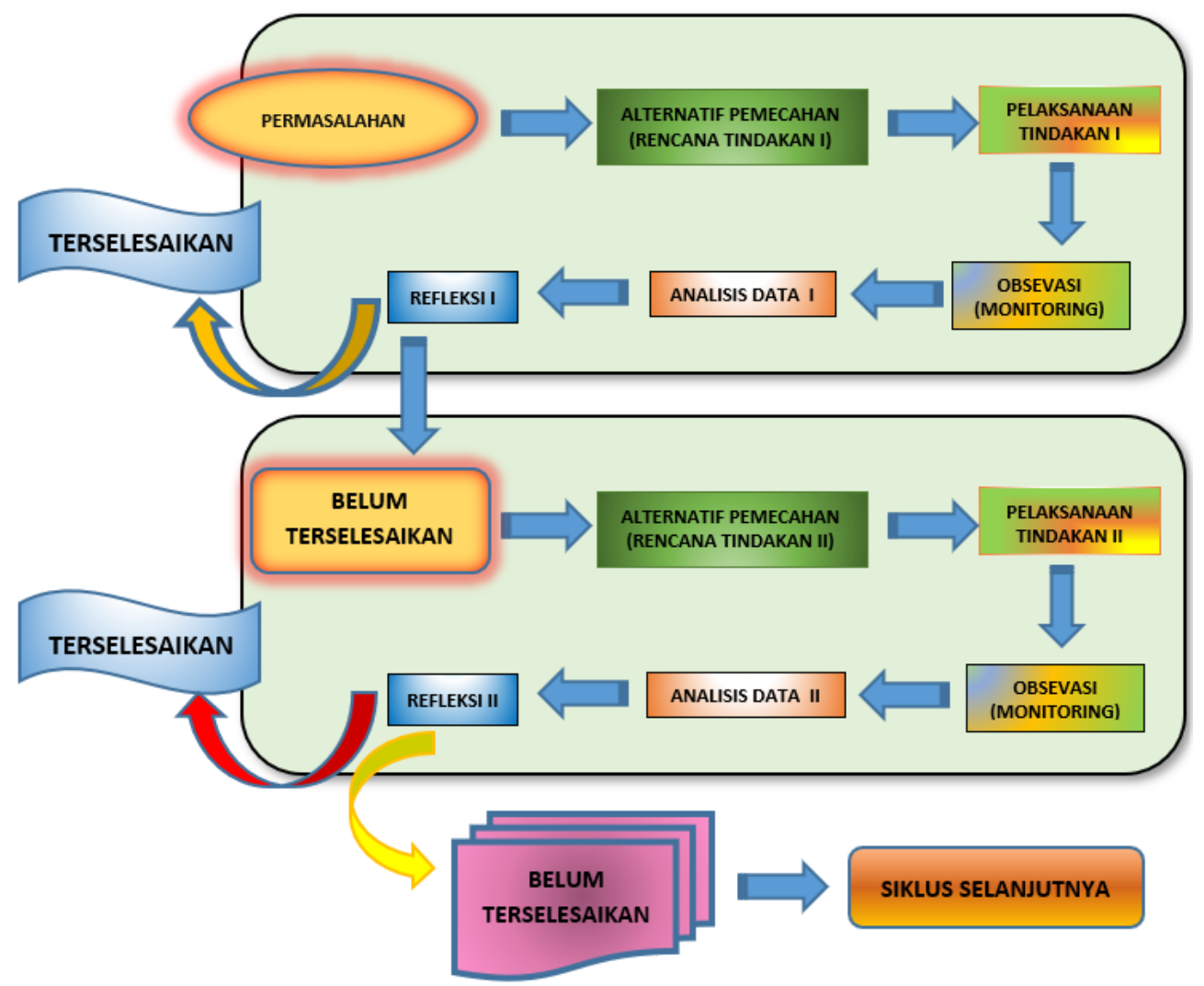

Gambar 1. Bagan Skema Penelitian Tindakan Kelas

\section{HASIL DAN PEMBAHASAN}

\section{Pra Penelitian}

Sebelum melaksanakan penelitian, peneliti terlebih dulu melakukan persiapanpersiapan agar komponen yang direncanakan dapat dikelola dengan baik. Hal yang penulis lakukan adalah membuat proposal penelitian, setelah itu penulis menentukan objek dan subjek penelitian. Kemudian penulis melanjutkan ketahap penelitian yang dimulai dari minggu pertama februari 2019.

\section{Siklus I}

Pada pelaksanaan proses kegiatan belajar mengajar di siklus I, penulis melaksanakannya pada minggu pertama dibulan februari 2019, yang dilaksanakan dikelas XIPM2 pada SMKN 1 Tanjungpinang, dengan jumlah siswanya sebanyak 29 siswa. Pada saat akan memulai terlebih dulu penulis mengawali dengan berdoa sesuai dengan agama dan kepercayaan masing-masing, setelah itu penulis mengecek kehadiran siswa, dilanjutkan dengan pengecekan kesiapan dari masing-masing kelompok, setelah itu penulis melanjutkan dengan menjelaskan tujuan pembelajaran khususnya materi ritel. Kemudian penulis lanjutkan dengan memberikan topik penjualan ritel untuk didiskusi kepada masingmasing kelompok, sambil menjelaskan sistem kerjanya, dengan tujuan agar masing-masing kelompok dapat melaksanakan dengan baik dan jelas.

Proses kegiatan pembelajaran pada siklus satu (I) ini, penulis lakukan sebanyak 2 kali pertemuan, untuk satu kali pertemuan menghabiskan 3 jam pelajaran atau 3 x 45 menit.

Pada saat penulis melaksanakan pembelajaran pada siklus satu (I), banyak hal yang penulis jumpai dikelas, diantaranya ada siswa yang benar-benar bersemangat dalam 
menanggapi materi ritel ini, ada juga diantaranya siswa yang tampak masih kurang berminat, sehingga ada diantaranya siswa yang masih kurang serius, hal ini terlihat masih ada diantaranya yang mengobrol pada saat teman kelompoknya diskusi. Setelah proses pembelajaran berlangsung disiklus I pada pertemuan pertama, untuk mengetahui hasil belajar siswa setelah diberi tindakan pada petemuan ke dua, yaitu masing-masing kelompok menyajikan hasil diskusinya didepan kelas, pada saat itulah penulis langsung memberikan penilaian yang sesuai dengan format yang telah penulis siapkan. Adapun yang menjadi acuan penilaian yaitu :

1. Format sikap pada saat diskusi kelompok

2. Format Penilaian diskusi kelompok

Masing-masing format penilaian diberi bobot yang berbeda, skor akhir penjumlahan merupakan hasil nilai yang diperoleh oleh siswa.

Tabel 2. Penilaian hasil belajar siswa disiklus I

\begin{tabular}{|c|c|c|c|}
\hline \multirow[t]{2}{*}{ No. Urut Siswa } & \multirow{2}{*}{$\begin{array}{ll}\begin{array}{l}\text { Nilai } \\
\text { diperoleh }\end{array} & \text { Yang } \\
\end{array}$} & \multicolumn{2}{|c|}{ Ketuntasan } \\
\hline & & $\mathrm{Ya}$ & Tidak \\
\hline 1 & 50 & & $\sqrt{ }$ \\
\hline 2 & 80 & $\sqrt{ }$ & \\
\hline 3 & 90 & $\sqrt{ }$ & \\
\hline 4 & 60 & & $\sqrt{ }$ \\
\hline 5 & 60 & & $\sqrt{ }$ \\
\hline 6 & 55 & & $\sqrt{ }$ \\
\hline 7 & 90 & $\sqrt{ }$ & \\
\hline 8 & 73 & & $\sqrt{ }$ \\
\hline 9 & 70 & & $\sqrt{ }$ \\
\hline 10 & 50 & & $\sqrt{ }$ \\
\hline 11 & 70 & & $\sqrt{ }$ \\
\hline 12 & 53 & & $\sqrt{ }$ \\
\hline 13 & 50 & & $\sqrt{ }$ \\
\hline 14 & 85 & $\sqrt{ }$ & \\
\hline 15 & 90 & $\sqrt{ }$ & \\
\hline 16 & 60 & & $\sqrt{ }$ \\
\hline 17 & 90 & $\sqrt{ }$ & \\
\hline 18 & 80 & $\sqrt{ }$ & \\
\hline 19 & 80 & $\sqrt{ }$ & \\
\hline 20 & 90 & $\sqrt{ }$ & \\
\hline 21 & 45 & & $\sqrt{ }$ \\
\hline 22 & 45 & & $\sqrt{ }$ \\
\hline 23 & 62 & & $\sqrt{ }$ \\
\hline 24 & 70 & & $\sqrt{ }$ \\
\hline 25 & 60 & & $\sqrt{ }$ \\
\hline 26 & 70 & & $\sqrt{ }$ \\
\hline 27 & 45 & & $\sqrt{ }$ \\
\hline 28 & 90 & $\sqrt{ }$ & \\
\hline 29 & 60 & & $\sqrt{ }$ \\
\hline Rata-rata & 68,03 & & \\
\hline Nilai tertinggi & 90,00 & & \\
\hline Nilai terendah & 45,00 & & \\
\hline \multicolumn{2}{|c|}{ \% Siswa yang tuntas } & 51,72 & \\
\hline \multicolumn{2}{|c|}{$\%$ Siswa yang tidak tuntas } & & 48,28 \\
\hline
\end{tabular}




\section{Vol. 1. No. 4 Desember 2021 e-ISSN : 2775-7188 | p-ISSN : 2775-717X}

Dari hasil penilaian diatas dapat ditarik suatu kesimpulan bahwa, persentase ketidaktuntasan siswa masih dibawah yang diharapkan, hampir mencapai 50\% siswa yang belum memenuhi Kriteria Ketuntasan Minimum atau (KKM) yang diharapkan yaitu 75 . Sedangkan untuk rata-rata kelas juga masih dibawah yaitu 68,03. Melihat hal tersebut maka penulis melakukan penilaian lagi pada tahap lanjutan siklus ke dua guna untuk melihat perbandingan antara proses disiklus I dan II.

\section{Siklus II}

Siklus ke dua ini penulis lakukan setelah siklus pertama belum mendapatkan hasil yang maksimal, sebagaimana yang diharapkan penulis, karena masih banyak siswa yang belum mencapai nilai KKM. Maka pada siklus ke II dipertemuan pertama ini penulis kembali menjelaskan materi ritel kepada siswa dengan harapan akan ada perubahan hasil yang lebih baik dari siklus I. Pada saat proses pembelajaran berlangsung penulis menggunakan metode pendekatan Contextual Teaching and Learning.

Dengan penerapan metode pembelajaran tersebut, Nampak adanya respon positif yang timbul dari masing-masing siswa pada pertemuan ke-2 disiklus II, apalagi pada saat proses diskusi berlangsung, siswa tampak lebih bersemangat dalam memberikan tanggapan, jawaban dan mengungkapkan pendapat serta melontarkan suatu pertanyaan kepada kelompok diskusi. Maka pada siklus ke II dipertemuan ke-2, penulis langsung melakukan penilaian. Setelah penulis melakukan tes penilaian kepada masing-masing kelompok siswa, hasil yang diperoleh sangat memuaskan, walaupun masih ada diantaranya siswa yang sedikit pasif sehingga mengakibatkan nilainya masih belum memuaskan. Namun jika dibandingkan dengan siklus ke I jauh lebih memuaskan pada proses pembelajaran di siklus ke II.

Hal ini dapat dilihat pada tabel hasil penilaian disiklus II.

Tabel 3. Penilaian hasil belajar siswa disiklus II

\begin{tabular}{|l|l|l|l|}
\hline \multirow{2}{*}{ No. Urut Siswa } & Nilai & Yang & \multicolumn{3}{|l|}{ Ketuntasan } \\
\cline { 3 - 4 } & diperoleh & Ya & Tidak \\
\hline 1 & 77 & $\sqrt{ }$ & \\
\hline 2 & 90 & $\sqrt{ }$ & \\
\hline 3 & 98 & $\sqrt{ }$ & \\
\hline 4 & 77 & $\sqrt{ }$ & \\
\hline 5 & 77 & $\sqrt{ }$ & \\
\hline 6 & 77 & $\sqrt{ }$ & \\
\hline 7 & 98 & $\sqrt{ }$ & \\
\hline 8 & 83 & $\sqrt{ }$ & \\
\hline 9 & 80 & $\sqrt{ }$ & \\
\hline 10 & 70 & & $\sqrt{ }$ \\
\hline 11 & 80 & $\sqrt{ }$ & \\
\hline 12 & 76 & $\sqrt{ }$ & \\
\hline 13 & 75 & $\sqrt{ }$ & \\
\hline 14 & 94 & $\sqrt{ }$ & \\
\hline 15 & 98 & $\sqrt{ }$ & \\
\hline 16 & 78 & $\sqrt{ }$ & \\
\hline 17 & 98 & $\sqrt{ }$ & \\
\hline 18 & 96 & $\sqrt{ }$ & \\
\hline 19 & 94 & $\sqrt{ }$ & \\
\hline 20 & 98 & $\sqrt{ }$ & \\
\hline 21 & 70 & & \\
\hline 22 & 76 & & $\sqrt{ }$ \\
\hline
\end{tabular}


Vol. 1. No. 4 Desember 2021 e-ISSN : 2775-7188 | p-ISSN : 2775-717X

\begin{tabular}{|l|l|l|l|}
\hline 23 & 77 & $\sqrt{ }$ & \\
\hline 24 & 80 & $\sqrt{ }$ & \\
\hline 25 & 78 & $\sqrt{ }$ & \\
\hline 26 & 78 & $\sqrt{ }$ & \\
\hline 27 & 74 & & $\sqrt{ }$ \\
\hline 28 & 98 & $\sqrt{ }$ & \\
\hline 29 & 78 & $\sqrt{ }$ & \\
\hline Rata-rata & 83,55 & & \\
\hline Nilai tertinggi & 98,00 & & \\
\hline Nilai terendah & 70,00 & & \\
\hline$\%$ Siswa yang tuntas & 89,66 & \\
\hline \% Siswa yang tidak tuntas & & 10,34 \\
\hline
\end{tabular}

Dari tabel diatas terlihat adanya perubahan yang begitu menonjol dibandingkan dengan penilaian pada siklus I, baik dari persentase ketuntasan belajar sampai nilai rata-rata kelas, semuanya sudah menunjukkan perubahan yang penulis inginkan walaupun masih ada yang belum memenuhi KKM, namun itu hanya sedikit saja dibandingkan dengan siklus I.

Dapat dilihat pada siklus II ini rata-rata ketuntasan siswa mencapai 83,55 nilai yang sudah melebihi KKM, begitu juga dengan jumlah persentase ketuntasan siswa hampir mencapai $90 \%$. Dan siswa yang belum tuntas hanya 10,34\%, Menurun jika dibandingkan dengan siklus I.

Dari tabel pada siklus I dan siklus II diatas dapat dibuat suatu perbandingan, yaitu:

Tabel 4. Perbandingan Persentase Ketuntasan

\begin{tabular}{|l|l|l|}
\hline Siklus I & Siklus II & Perbedaan \\
\hline 51,72 & 89,66 & 37,94 \\
\hline
\end{tabular}

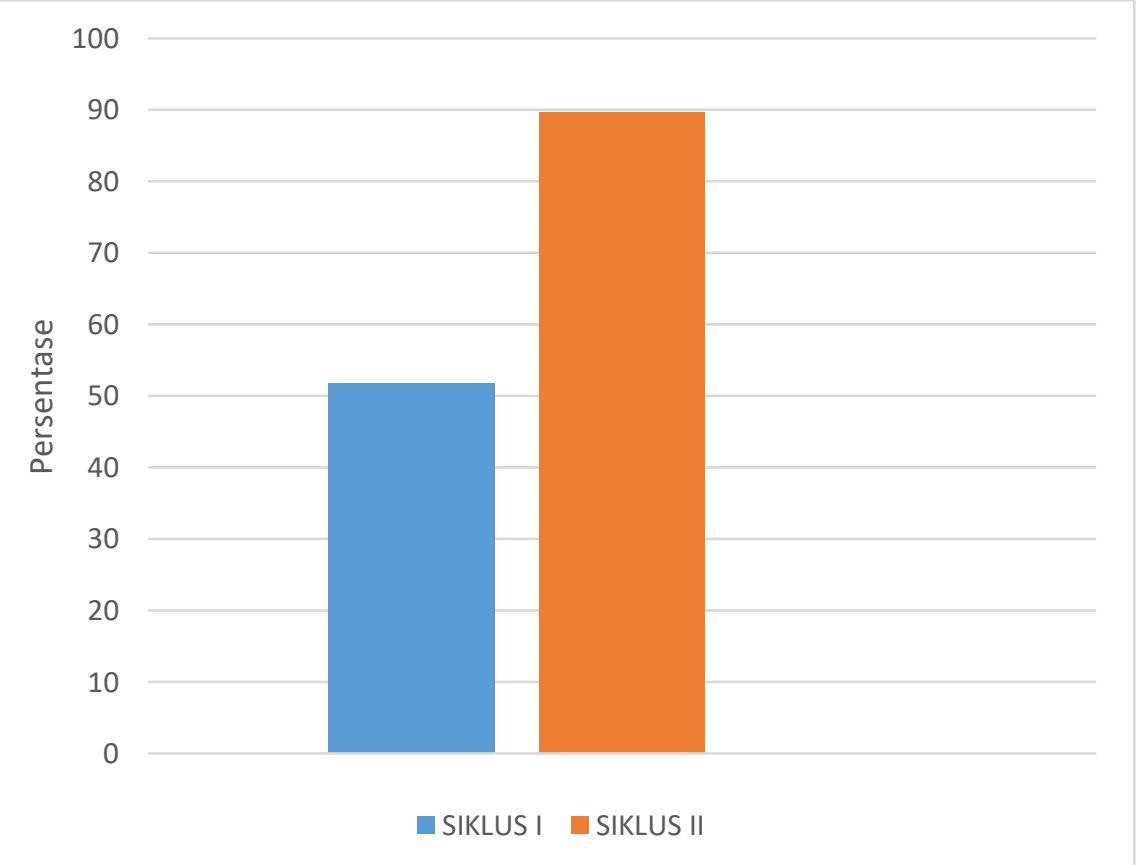

Gambar 1. Grafik Persentase Ketuntasan Belajar Siswa

Dari gambar Tabel 4 dan Grafik 1 tentang Persentase Ketuntasan Belajar Siswa, jelas terlihat perbandingan antara siklus satu (1) dan Siklus dua (2) yaitu kekuntasan belajar dengan menggunakan metode Contextual Teaching and Learning ( CTL) pada siklus I 
hanya mencapai $51,72 \%$, sedangkan pada siklus II hampir mencapai $90 \%$ pada mata pelajaran Ritel.

Tabel 5. Perbandingan Nilai Rata-Rata Kelas

\begin{tabular}{|l|l|l|}
\hline Siklus I & Siklus II & Perbedaan \\
\hline 90,00 & 98,00 & 8,00 \\
\hline
\end{tabular}

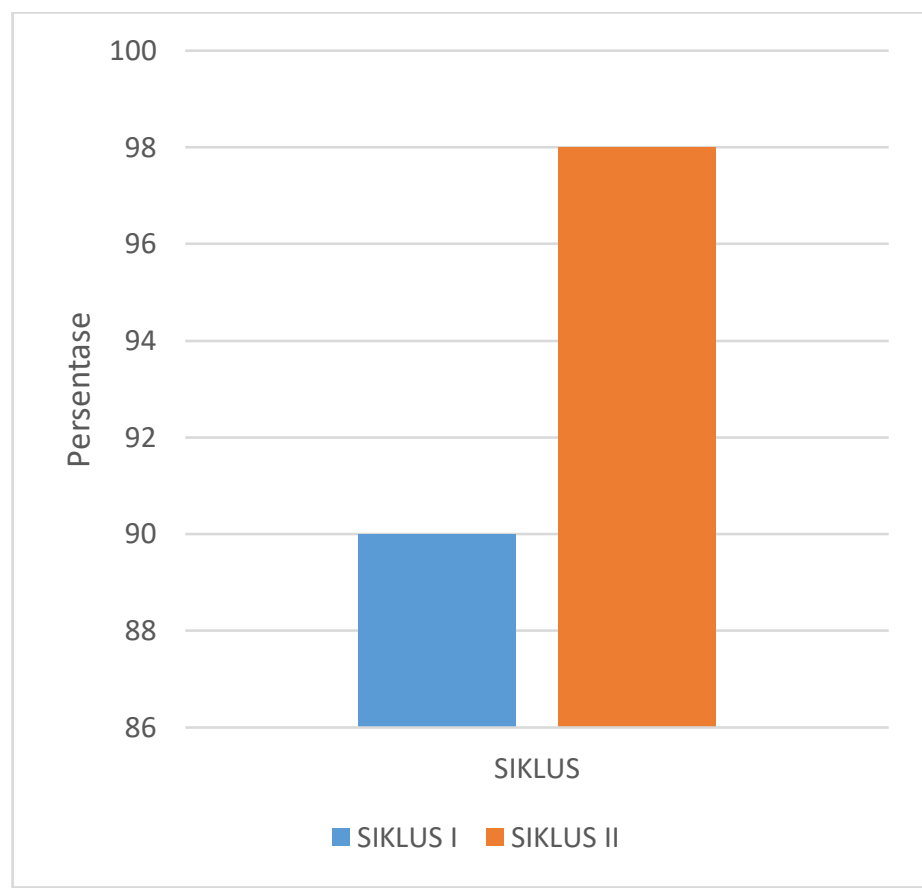

Gambar 2. Rata-Rata Nilai Siswa

Berdasarkan Tabel 5 dan Grafik 2 diatas dapat ditarik suatu Kesimpulan bahwa, dengan adanya model Pembelajaran Contextual Teaching and Learning atau (CTL) hasil belajar siswa meningkat dengan baik. Hal ini dapat dilihat dari Rata-rata Nilai Siswa pada Perbandingan Siklus I dan Siklus II, dimana pada siklus I Rata-rata kelas mencapai 90\%, sedangkan pada siklus II meningkat menjadi $98 \%$.

\section{Pembahasan}

Model pembelajaran adalah serangkaian kegiatan yang dirancang oleh guru untuk dilakukan oleh siswa dalam proses pembelajaran agar tujuan pembelajaran dapat tercapai sesuai dengan yang diharapkan.

Model pembelajaran yang digunakan dalam penelitian ini adalah Contextual Teaching Learning (CTL), yaitu konsep belajar dimana guru menghadirkan dunia nyata didalam kelas dan mendorong siswa membuat hubungan antara pengetahuan yang dimilikinya dengan penerapannya dalam kehidupan mereka sehari-hari, sementara siswa memperoleh pengetahuan dan ketrampilan dari kontek yang terbatas, sedikit demi sedikit dan dari proses mengkonstruksi sendiri sebagai bekal untuk memecahkan masalah dalam kehidupannya sebagai anggota masyarakat.

Karekteristik pembelajaran kontekstual menurut Jhonson ( dalam Nurhadi, 2004 : 13) ada delapan komponen pembelajaran kontekstual, yaitu :

1. Melakukan hubungan yang bermakna

2. Melakukan kegiatan-kegiatan yang siknifikan

3. Belajar yang diatur sendiri

4. Bekerjasama

5. Berpikir kritis dan kretif

6. Mengatur dan memelihara pribadi siswa

7. Mencapai standar yang tinggi 
8. Menggunakan penilaian yang autentik

Pembelajaran melalui CTL pada dasarnya mendorong siswa agar bisa mengkonstruksi pengetahuannya melalui proses pengamatan dan pengalaman. Karena pengetahuan yang hanya diberikan tidak akan menjadi suatu fenomena, jika tidak dilanjutkan dengan kegiatankegiatan yang bermakna guna untuk menghasilkan temuan yang diperoleh oleh siswa itu sendiri. Komponen menemukan merupakan kegiatan inti dari CTL, kegiatan ini diawali dari pengamatan terhadap fenomena, kemudian dilanjutkan dengan kegiatan-kegiatan yang bermakna untuk menghasilkan temuan yang diperoleh oleh siswa. Dengan demikian pengetahuan dan ketrampilan yang diperoleh oleh siswa tidak hanya dari hasil mengingat seperangkat fakta saja, tetapi juga hasil dari menemukan sendiri dari fakta yang dihadapinya.

Dalam pembelajaran CTL penilaian tidak hanya dilakukan diakhir semester saja, namun dilakukan bersama dan terintegrasi dari proses kegiatan pembelajaran. Penilaian autentik diarahkan pada proses mengamati, menganalisis dan menafsirkan data yang telah dikumpulkan siswa ketika proses pembelajaran siswa berlangsung, bukan semata-mata hasil pembelajaran.

Yang menjadi prinsip dasar Penulis dalam menerapkan penilaian autentik adalah :

1. Untuk mengetahui perkembangan belajar siswa

2. Untuk memberikan kesempatan kepada siswa agar dapat mengembangkan penilaian diri dan penilaian sesamanya

3. Penilaian dilakukan secara komprehensif dan seimbang antara penilaian proses dan hasil

Model-model pembelajaran konvensional yang berpusat pada guru dan siswa segagai obyek belajar sudah harus ditinggalkan, kemudian menuju ke model-model pembelajaran yang memanusiakan peserta didik dengan melibatkan secara aktiv dan tidak menganggap lagi siswa sebagai obyek belajar, tetapi harus menjadi subyek (pelaku) belajar.

\section{KESIMPULAN}

Setelah penulis melakukan Penelitian Tindakan Kelas selam kurang lebih 2 Bulan, dapat penulis Tarik suatu kesimpulan bahwa :

Proses pembelajaran dengan melibatkan teman kelompok dapat membuat suatu motivasi belajar yang baik, hal ini terlihat pada presentase ketuntasan belajar siswa pada siklus I dan siklus II, yaitu persentase ketuntasan pada siklus I terlihat 51,72 \% dan terdapat $41,28 \%$ yang tidak tuntas, sehingga terjadi perubahan setelah dilakukan siklus II yaitu terdapat ketuntasan belajar siswa 89,66\% dari 10,34 yang tidak tuntas, dengan nilai rata 83,55. Kemudian nilai tertinggi terdapat 98,00 sudah mencukupi KKM yang ditentukan. Dan nilai terendah pada siklus II 70,00. Itupun hanya diperoleh tiga orang siswa dari 29 orang siswa.

Sedangkan pada siklus I terdapat rata-rata nilai kurang dari KKM yang telah ditetapkan yaitu 68,03, nilai terendah 45,00 dan nilai tertinggi 90,00 yang hanya didapatkan oleh satu orang siswa. Pada siklus I ini terdapat siswa yang tuntas hanya 52,72\% untuk siswa yang tidak tuntas 48,28\%, sedangkan KKM untuk ketuntasan 75,00.

Maka dari itu dengan adanya perubahan model pembelajaran akan mengakibatkan suatu perubahan pola piker dan daya serap siswa, sehingga memperoleh hasil yang diharapkan atau hasil yang lebih baik.

Disini penulis sarankan dalam melakukan proses pembelajaran, hendaklah menggunakan metode-metode pembelajaran yang mungkin membuat siswa tertarik dan mampu memahami dan mencerna materi yang akan disampaikan, sehingga siswa benarbenar mampu menerapkannya, baik untuk dirinya sendiri ataupun untuk orang lain.

Selain itu untuk menentukan metode pembelajaran yang akan diterapkan ke siswa, hendaklah terlebih dulu mengadakan penelitian lebih lanjut dikelas yang berbeda.

Dalam hal ini proses pembelajaran dengan menggunakan pendekatan Contextual Teaching and Learning (CTL) dapat meningkatkan hasil belajar siswa kearah yang lebih baik. 


\section{DAFTAR PUSTAKA}

Almasdi Syahza. (2009). Metodologi Penelitian. pusbangdik Universitas Riau. Pekanbarau Hendripides. (2012). Pendidikan dan Latihan Profesi Guru. FKIP UNIVERSITAS RIAU: Jakarta

Nurhadi. (2004). Pembelajaran Kontekstual dan Penerapannya dalam KBK. Universitas Malang, Malang

Panitia Sertifikasi Guru Rayon 105, Bahan ajar Sertifikasi Guru. 2012. FKIP UNIVERSITAS RIAU

Rozaniwati dan Tata Purwata. (2008). Modul Membuka Usaha Eceran Ritel. Erlangga. Jakarta Suharsimi Arikunto, Suhardjono dan Supardi. (2006). Penelitian Tindakan Kelas. Bina Aksara 